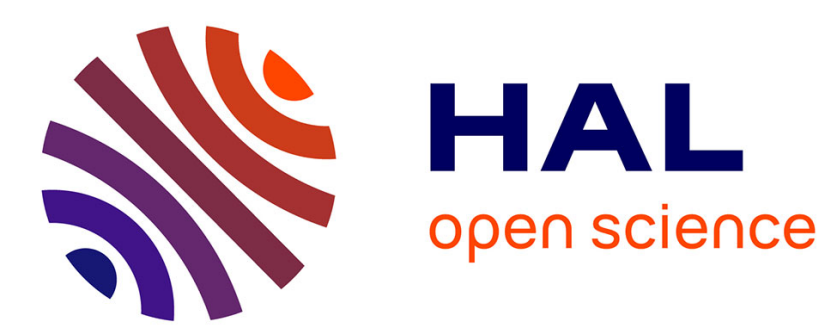

\title{
How (Not) to Lead Academia
}

\author{
Miguel Abambres
}

\section{To cite this version:}

Miguel Abambres. How (Not) to Lead Academia. 2019. hal-02281227v4

\section{HAL Id: hal-02281227 \\ https://hal.science/hal-02281227v4}

Preprint submitted on 17 Nov 2019

HAL is a multi-disciplinary open access archive for the deposit and dissemination of scientific research documents, whether they are published or not. The documents may come from teaching and research institutions in France or abroad, or from public or private research centers.
L'archive ouverte pluridisciplinaire HAL, est destinée au dépôt et à la diffusion de documents scientifiques de niveau recherche, publiés ou non, émanant des établissements d'enseignement et de recherche français ou étrangers, des laboratoires publics ou privés. 


\section{How Not to Lead Academia}

\section{Abambres $\underline{\mathrm{GS}}$, $\underline{\text { email }}$}

Co-Authorship Invitation: Anyone supporting all ideas presented in this manuscript can become co-author without adding any content. This is perfectly OK for me, since this is an opinion paper, and thus the more it is disseminated, the more likely those ideas are made real in a near future. If you want me to add you as co-author, please send me your name and affiliation by email.

(C) 2019 by Abambres M (CC BY 4.0)

ID: hal-02281227

Abstract: This work reports several issues found by the author throughout his professional career, concerning academic leadership. Topics like (i) out-of-field teaching/researching, and (ii) time management in faculty hiring or new role assignment, are addressed. Besides, the author describes which fundamental decisions he'd take if he could manage a higher education institution or academic department. The topics covered are crucial for the success of any higher education institution, such as (a) hiring, (b) social engagement, (c) student assessment, (d) open mindedness, (e) prompt communication, (f) passion in work, and (g) freedom / trust.

Keywords: Academia, Scholars, Higher Education, Schools, Universities, Academic Leadership, Academic Management, Hiring, Out-of-Field Teaching/Researching, Passion in Work, Freedom, Trust.

\section{Academic Leadership}

In the recent past, a lot of attention has been devoted to student mental health on university ${ }^{1}$ campi. Research has shown that a large portion of students experience prominent levels of depressive symptoms, and that a significant portion of scholars are at risk of burnout (Gorczynski 2018). Naturally, both previous facts are deeply related, since poor mental health have profound impact on the competence and productivity of academics.

\footnotetext{
${ }^{1}$ From now on, 'university' might be used to refer to any type of higher education institution.
} 
ID: hal-02281227

(C) 2019 by Abambres M (CC BY 4.0)

Causing people to supress parts of their identity is limiting a valuable source of creativity. Managers should encourage identity integration (e.g., female engineers working in an environment where they don't feel they have to dress like men) in order to boost innovation (Amabile and Khaire 2008). Richard Ingersoll, professor of Education and Sociology at the University of Pennsylvania, has done extensive research on teacher retention and quality. His studies reveal that most teachers have little input into the decisions that affect their work, and this lack of control drives many out of the classroom (Langhorne 2018). A recent report from the Consortium for Policy Research in Education shows that schools with (i) higher levels of teacher leadership - the amount of input teachers have in school decision-making, and (ii) higher focus on teaching and learning, produce greater student achievement (Langhorne 2018). Leadership is seen as the single key component in determining the success of a school (du Plessis et al. 2014). Teachers must be able to lead in the areas they are passionate about (Maiers 2019). According to teacherpowered.org, there are more than 120 teacher-powered public schools in USA, spanning at least 19 states and serving students from preschool to age $21.85 \%$ of Americans agree teacher-powered schools are a good idea. These schools are not 'anti-principal'; instead, they are managed by true leaders (Langhorne 2018).

Aristotle (384 - 322 B.C), a prodigious Greek researcher and writer (see Fig. 1), is amongst the greatest philosophers of all time. In areas such as logic, metaphysics and philosophy of mind, ethics, political theory, aesthetics and rhetoric, and empirical biology, Aristotle's theories have (i) provided interest and illumination, (ii) met with confrontation, and (iii) sparked debate (Shields 2016). For Aristotle (Abambres 2019), a leader is the one caring about your happiness and creating the conditions for you to find your perfect role in the system (e.g., a company). According to Aristotle, if you are passionate at work, instead of fearful of (i) being fired, (ii) not getting a raise, (iii) not being promoted, or (iv) getting your values and opinions rejected or criticized (etc.), your performance will be way more effective. 
ID: hal-02281227

(C) 2019 by Abambres M (CC BY 4.0)

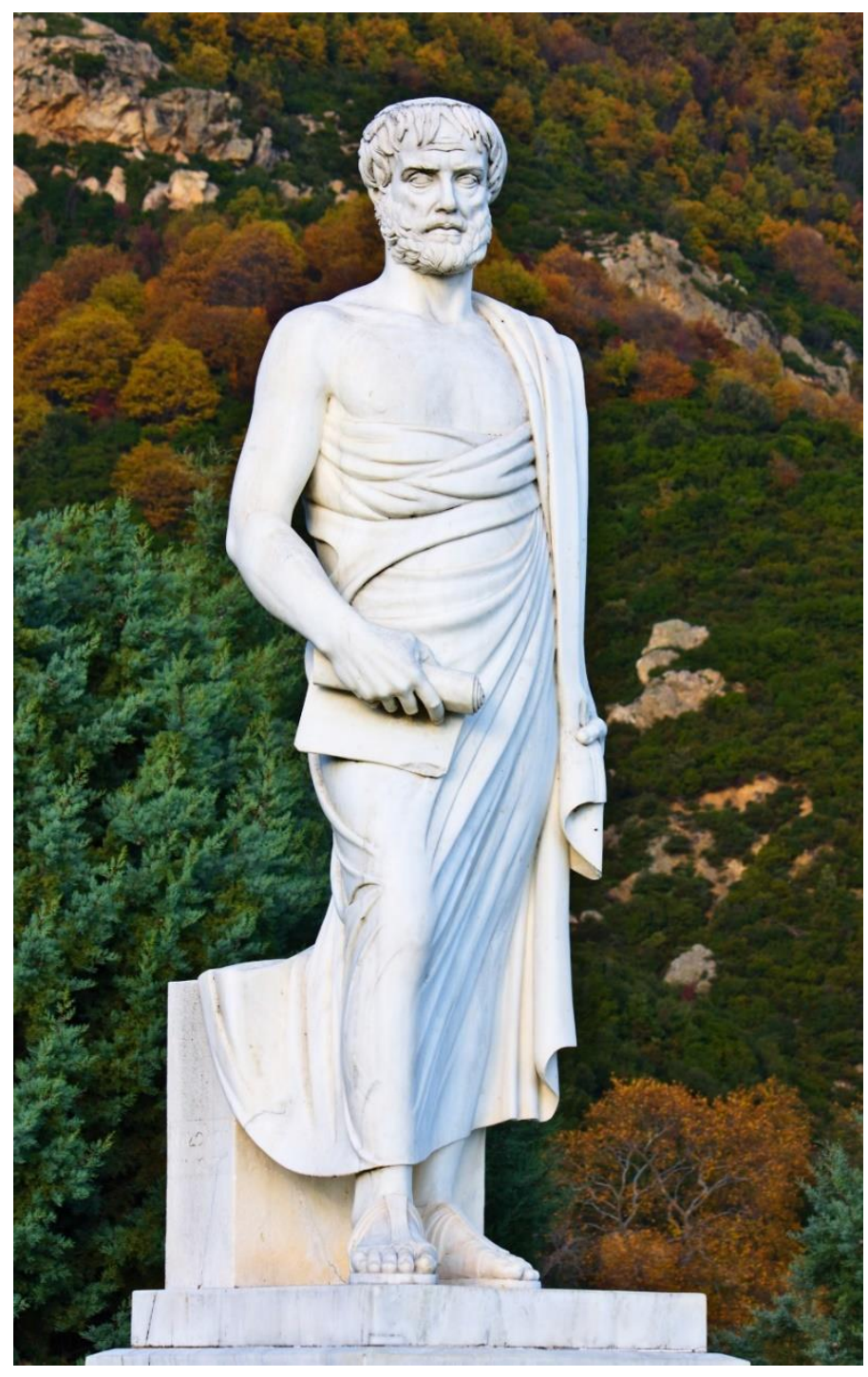

Fig. 1. Statue of Aristotle in Stagira, Greece (taken from URL).

Throughout our careers we are taught to conform to the status quo, i.e. to the opinions and behaviors of others. Organizations and their workers both pay a price: decreased engagement, 
ID: hal-02281227

(C) 2019 by Abambres M (CC BY 4.0)

productivity and innovation. According to Gino (2016), if you want engaged employees, you should encourage them to question the status quo and bring out their signature strengths.

"Those who are crazy enough to think they can change the World, are the ones who do", Steve Jobs

\section{Out-of-Field Teaching/Researching}

Hiring new professors is among the most consequential work done by academic departments, but the conduct of such tasks has often been left undiscussed (Chambliss 2006). A solid consensus, based on research and common sense, recognizes that teachers must be knowledgeable about the subjects they teach if they are to help all students achieve high academic standards (Jerald and Ingersoll 2002). According to Chambliss (2006), a well-tested rule to handle faculty searches, aimed at hiring the best possible person for the job, is to hire for demonstrated strength and not for lack of weakness - too often, candidates are eliminated for what they can't do. If one hires for lack of weakness, what remains is one person who appears to be good at everything but great at nothing. Unfortunately, some colleagues insist on requiring that all their faculty be proficient in multiple unrelated areas. Many ask (i) great teachers to be productive scientists, (ii) the most dedicated researchers to spend time meeting with assistant deans on faculty governance committees, or (iii) gifted student advisors to win grants from the National Science Foundation, and when they don't they get fired - a terrible waste (Chambliss 2006). The standard issue "balance of teaching, scholarship, and service" is a recipe for mediocrity, in which each individual, rather than the organization as a whole, must include all the needed skills. The result will be everybody trying to shore up their weaknesses instead of being spectacular successes in their strong areas (Chambliss 2006). In any case, the best hiring strategy is to hire someone who's great at something and place 
D: hal-02281227

(C) 2019 by Abambres M (CC BY 4.0)

him/her where that strength will do the most good. When hiring new talent, Finnigan (2014) believes that passion can actually play a greater role than experience towards success. Kiesa Kelly $(\mathrm{PhD})$, chair of the psychology department at Tennessee State University, aims to hire candidates who (Abrams 2018) are passionate about (i) teaching, (ii) mentorship and (iii) cultural competence, instead of hiring for the (a) reputation of the institutions in their $\mathrm{CV}$, and (b) publication record (a strongly criticized matter in Abambres et al. 2018, 2019).

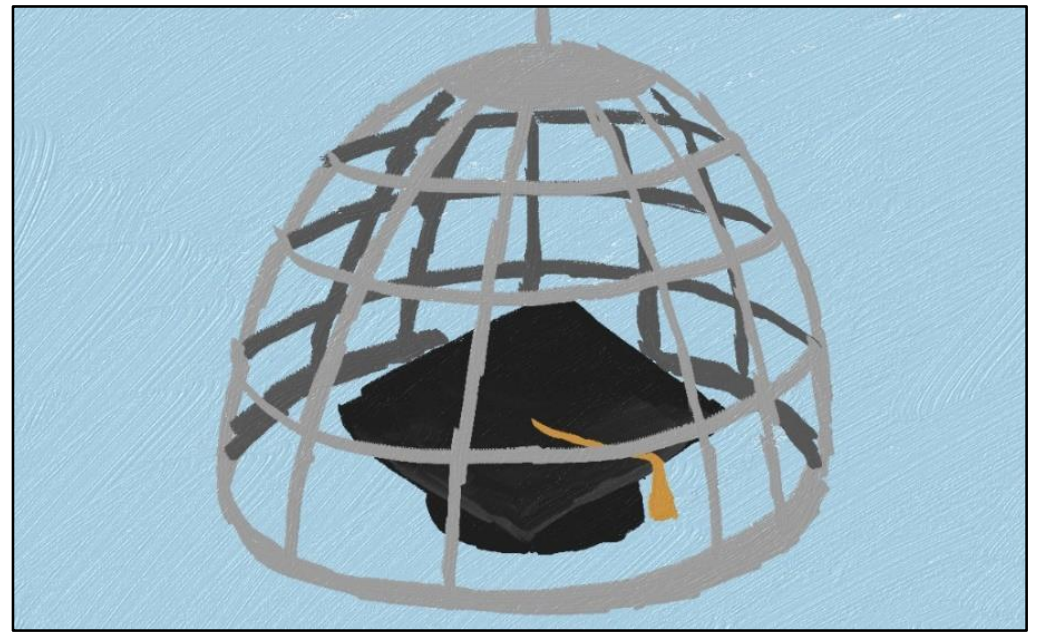

Fig. 2. Out-of-field (or at least "out-of-passion") researching also occurs, inclusively with students, as reported in here.

For Smoot (2013), great teachers are passionate about the content of their teaching. Nevertheless, as most faculty know, it's not uncommon to be asked to teach a course you don't feel fully prepared to, especially if you are a junior faculty member. The issue of careless assignment of teachers is not new and is a universal problem, but in the past two decades it has become to be seen as one of the major hindrances to quality education. A major issue is knowing why something is important in an area outside your expertise (Rhem 2010), but the worst 
ID: hal-02281227

(C) 2019 by Abambres M (CC BY 4.0)

consequence is perhaps the creation of a vicious cycle (Sambe 2015) - a teacher not satisfied with the job resigns, leaving an urgent vacancy that needs to be filled quickly by the administration, which most likely hires an out-of-field teacher (the easy way). Research has found that teaching out-of-field can compromise "teaching competence" - e.g., ineffective teaching methods are likely to be used, teacher's identity and well-being are disrupted, and it's often associated with teacher strain and attrition (Hobbs 2014, 2015, Sambe 2015). Education institutions are becoming too much like businesses - teachers and students don't really matter, which ignores the unique purpose of those organizations - providing an effective teaching and learning environment.

\section{Time Management in Faculty Hiring or New Role Assignment}

In my experience ${ }^{2}$ (including testimonials from other academics I've met), virtual all higher education private institutions show terrible time management skills in faculty hiring or new role assignment (for faculty already employed by the institution). They simply don't assign a new job early enough (i.e., at least 1 month per course prior the start of the semester) so that professors are able to thoroughly prepare their classes. They just don't care! Not even when they get spontaneous applications way before the beginning of classes or are aware in advance about professors' aims to teach new courses. Authorities of higher education institutions do not understand that this bad time management jeopardizes education and their business. With lack of time to prepare lectures, professors (i) might get anxious, (ii) might miss important hours of sleep, (iii) won't have enough time to update their classes based on the state of art, (iv) won't have enough time to improve the teaching methods, and (v) might have to stop researching to manage preparing all lectures in time. Both professors and students are negatively affected.

\footnotetext{
${ }^{2,3}$ Already quite vast, although still a young professional (check my LinkedIn).
} 
ID: hal-02281227

(C) 2019 by Abambres M (CC BY 4.0)

\section{Higher Education Management: Abambres' proposal}

Next I'm describing in an upfront manner which fundamental decisions I'd take if I could manage a higher education institution or academic department. That decision-making is crucial for the success of any higher education institution, and according to my experience ${ }^{3}$ it has not been adopted by most private universities. For me the University should not be a place to prepare people for real life, but a place to teach them how to be happier and change real life for better.

\subsection{Hiring}

$I^{\prime} d$ hire only passionate and proactive people and I'd offer them jobs that would fully comply with their passions. Concerning faculty hiring or role assignment for teaching, every employee would have been assigned any course (and respective syllabus, if not to be created from scratch by the employee) at least 2 months before the beginning of classes. A contract would be signed as soon as any professor knew all the teaching duties for the new semester.

\subsection{Social Engagement}

Building relationships with students beyond the classroom can help drive learning, since they typically work harder with people they have empathy with (Maiers 2019, Brooks 2019). I have felt throughout my experience that there's a lack of social engagement with students and other faculty in private universities, especially in Portugal. In South America, people are more open minded and talkative, which helps even if no social engagement is promoted by the university. Creating noncompulsory ways of social engagement is always beneficial because (i) everyone is free not to participate, and (ii) it's an opportunity to get more empathy with students and colleagues, which increases happiness in work. 
ID: hal-02281227

(C) 2019 by Abambres M (CC BY 4.0)

\subsection{Student Assessment}

In my opinion all tests or exams should be multiple-choice-based and carried out in institutional computers for that purpose. A software should be created so that those types of assessment are immediately classified, saving lots of time to professors (who could use it to rest more, improve their classes, or research). In my opinion (I might publish a paper about it soon), it's perfectly possible to assess (i) theoretical questions, (ii) reasoning questions, and (iii) the ability to get the right numerical solution of a problem, via multiple-choice tests. Moreover, it can be perfectly guaranteed (via correction criteria and the amount of answer choices per question) no risk of cheating and very low chances of selecting right answers by luck. Furthermore, group or individual home assignments should be evaluated by oral presentation in classroom only, i.e. every assessment in any course would be based on student's performance in the class/assessment room.

\subsection{Open Mindedness}

Authorities (deans, directors, academic coordinators) in academia should be highly open minded. Open mindedness is key for the development of creative and innovative work and decisions. All authorities should be open to the proactiveness of their employees, who (like me) might constantly be thinking on ways to improve their working conditions and to attract more professionals and students to be part of the university. People like me straightforwardly email/text authorities to share negative facts about the university (e.g., noisy library, outdated/damaged hardware and software) or suggest improvements. Unfortunately, I've felt that most authorities don't like nor encourage this type of communication. In my experience, most of them not even answer my emails.

\subsection{Prompt Communication}

Some academic authorities (deans, directors, academic coordinators) take too much time to reply to emails or any other type of digital communication. Some don't even care about replying 
ID: hal-02281227

(C) 2019 by Abambres M (CC BY 4.0)

at all (even when we get to know that messages are received and read - e.g., WhatsApp). The minimum that should be done would be replying within 24 (ideally)-36 hours to let the sender know his/her message was received and will be carefully analyzed sometime soon. If one is too busy to make it possible, that task should be assigned to someone else.

\subsection{Passion}

The way to maximize any company's performance is to hire passionate people only. Research shows that the best teachers are passionate about teaching and driven by a deep desire to help others (Hattie and Clinton 2008). I wouldn't hire people who work for other companies outside academia. It turns out that those employees are not passionate enough about teaching or researching. Those who do, think their time is too short to work, get new knowledge, and improve their skills. Working outside academia typically makes those employees perform crucial academic duties in a rush, which jeopardizes education. The real passionate people I'd hire would be the ones who don't have many passions - those who like to focus on a few areas so they can excel in all of them.

According to Murray (2019), passionate teachers are those committed to students' success, i.e. showing students how education can be used to achieve their goals/passions - sometimes called passion-based learning, instead of focusing on the achievement of good grades. By doing what they love, students learn to try hard, take risks, and 'never' quit. Being around passionate people is the best way to become passionate (Hatfield et al. 1994, Maiers 2019), which can drive success.

"The lecturer should give the audience full reason to believe that all his/her powers have been exerted for their pleasure and instruction", Michael Faraday (in AMM 2019). 
ID: hal-02281227

(C) 2019 by Abambres M (CC BY 4.0)
"Teaching is not a profession; it's a passion. Without passion for your subject and a desire for your students to learn and be the best in the World, then we have failed as a teacher", John F. Podojil (in AMM 2019).

"Don't ask yourself what the World needs, ask yourself what makes you come alive and then go and do that. Because what the World needs is people who come alive", Howard Thurman (in Maiers 2017).

\subsection{Freedom / Trust}

Most of private universities I already worked for care more about student complaints than what hired faculty think to be the best teaching methods for a particular course. Regardless the number of complaints, those coordinators and directors believe that the best education is the one leading to immediate happiness during any class. According to opinions from Clóvis de Barros Filho, Kant (renowned philosophers) and mine, those academic authorities are fully wrong (Abambres 2019). Educating in that way makes Man's growth unfeasible, because an effective education process must include student discomfort, 'pain', mistakes, correction or warning. Acting in higher education like students are dumb or still children, hyper-protecting them, will definitely slow down the development of their intellectual capacity. Examples of such behavior by academic authorities are: 
ID: hal-02281227

(C) 2019 by Abambres M (CC BY 4.0)

- Asking faculty not to present power point slides with contents not in the national language, even though the class is fully given in the national language and the secondary languages used in slides are the two most popular in the western world (Spanish and English). Moreover, one should bear in mind that faculty might have no other choice than using other languages (e.g., from textbooks used to prepare the classes, from presentations previously prepared for a foreign audience) to guarantee that classes are prepared on time, as consequence of the awful time management practiced by academic authorities (see section 3 ).

- Asking faculty to solve all the exercises on the classroom board, step-by-step, instead of explaining the step-by-step resolution in power point slides made available to every student. They argue that if we don't do it on the board, students won't follow all our reasoning and won't have the courage to tell the professor they don't understand some step $(\mathbf{L o L})$.

"It doesn't make sense to hire smart people and tell them what to do; we hire smart people so they can tell us what to do", Steve Jobs (in Schroeder 2018).

\section{Acknowledgements}

I dedicate this paper to my beloved parents Ana Abambres and José Abambres, my cats Tiger and Cheetah, and all those who enjoy and support my work and mindset. 
ID: hal-02281227

(C) 2019 by Abambres M (CC BY 4.0)

\section{References}

A Motivating Moments, LLC (AMM) (2019). Leaders and Leadership Quotes. Available at motivateus [Accessed January 23].

Abambres M (2019). Mentes Brilhantes (in portuguese). Video privately stored [email me to get it].

Abambres M, Ribeiro T, Sousa A, Lantsoght E (2018). Research Counts, Not the Journal, hal02074859

Abambres M, et al. (2019). Bye Bye Peer-Reviewed Publishing, hal-02114531

Abrams Z (2018). Academic careers: 8 steps for hiring the faculty of your dreams. Available at APA [Accessed January 21, 2019].

Amabile T, Khaire M (2008). Creativity and the Role of the Leader. Harvard Business Review. Available at hbr [Accessed January 23, 2019].

Brooks D (2019). Students Learn From People They Love. Available at nytimes [Accessed January 18].

Chambliss DF (2006). Hiring Departmental Faculty. Available at hamilton [Accessed Jan 23, 2019].

du Plessis AE, Carroll A, Gillies RM (2014). The meaning of out-of-field teaching for educational leadership. Int Journal of Leadership in Education, doi: 10.1080/13603124.2014.962618

Finnigan D (2014). Hiring for Passion, Not Experience. Available at inc [Accessed January 21, 2019].

Gino F (2016). Let Your Workers Rebel - the big idea. Harvard Business Review. Available at hbr [Accessed June 27, 2019].

Gorczynski P (2018). More academics and students have mental health problems than ever before. Available at theconservation [Accessed January 18, 2019].

Hatfield E, Cacioppo JT, Rapson RL (1994). Emotional Contagion. Cambridge University Press (UK), ISBN: 9780521449489

Hattie JAC, Clinton J (2008). Identifying accomplished teachers: A validation study. Assessing teachers for professional certification: The first decade of the National Board for Professional Teaching Standards. Advances in Program Evaluation Series \#11, Oxford (UK), pp. 313 - 344.

Hobbs L (2014). Teaching Science Out-of-Field. Encyclopedia of Science Education. Springer, Dordrecht, doi: 10.1007/978-94-007-6165-0_211-2

Hobbs L (2015). Too many teachers teaching outside their area of expertise. Available at theconversation [Accessed January 23, 2019]. 
ID: hal-02281227

(C) 2019 by Abambres M (CC BY 4.0)

Jerald CD, Ingersoll R (2002). All Talk No Action: Putting an End to Out-of-Field Teaching. Retrieved from upenn 142 [Accessed January 2019].

Langhorne E (2018). The Teacher-Powered Schools Movement: Transforming Teachers from Industrial Workers to Professionals. Available at forbes [Accessed January 18, 2019].

Maiers A (2017). Genius Matters - A framework for epic transformation. Choose2Matter, Inc, New York (USA), ISBN: 978-1-365-02500-6.

Maiers A (2019). Guidelines of Passion-Based Learning. Available at angelamaiers [Accessed January 23].

Murray J (2019). Teaching Strategies to Help Students Find Their Passion. Available at teachhub [Accessed June 29].

Rhem J (2010). Tomorrow's Teaching and Learning - Teaching What You Don't Know. National Teaching and Learning Forum Newsletter, 19(3). Available at tomprof stanford [Accessed June 27, 2019].

Sambe M (2015). Out-of-Field Teaching - Consequences of teachers teaching out of their field of study. Available at tapmagonline [Accessed January 23, 2019].

Schroeder P (2018). Hire Smart People and Let Them Tell You What To Do - Just Like Steve Jobs Did. Available at hackernoon [Accessed January 19, 2019].

Shields C (2016). Aristotle. The Stanford Encyclopedia of Philosophy. Available at stanford [Accessed Jun 29, 2019].

Smoot B (2013). Passion and Awareness: What Great Teachers Have in Common. Available at higheredjobs blog [Accessed January 23, 2019]. 